\title{
Adeziv sistemlerde güncel yaklaşımlar
}

\section{Current approaches in adhesive systems}

\author{
Nihan CEVLEK $\square$, Didem ATABEK $\square$
}

Çocuk Diş Hekimliği ABD, Gazi Üniversitesi Diş Hekimliği Fakültesi, Ankara/TÜRKIYE

\section{Öz}

Diş çürüğü küresel ölçekte yaygın bir hastalıktır. Rezin kompozitler, diş dokularına adeziv sistemlerle bağlanarak çürükleri restore etmek için kullanılan en popüler malzemelerdir.Adeziv sistemler, içerdikleri bileşenler ile hem substrat yüzeyini hazırlar hem de restoratif materyale bağlanarak iki farklı yapı arasında hibrit bir tabaka oluşturur. Bu tabaka zamanla yıkıma maruz kalmaktadır.Bu nedenle, gelecekte yeni malzeme ve tekniklerin uygulanmasını desteklemek için hibrid tabakanın bozulma ve stabilizasyon mekanizmalarına ilişkin faktörlerin gözden geçirilmesi önemlidir.Bu derlemenin amacı dentin adezyonu kapsamında hibrit tabakaya yönelik çalışmaların etkilerini okuyucuya sunmaktır.

Anahtar kelimeler: adezyon; dentin proteinizasyonu; matriks metalloproteinazlar

\section{Abstract}

Dental caries is a common disease on a global scale. Resin composites are the most popular materials to restore caries by bonding to tooth tissues via adhesives. The constituents of the comtemporary adhesive systems not only prepare the dental subtsrate but also adhere to the restoration material by forming an hybrid layer.This hybrid layer thus the restorations are vulnerable to degradation in time.Hence, it is important to review the factors related to the mechanisms of degradation and stabilization of the hybrid layer to support the implementation of new materials and techniques in the future. The aim of this review is to present the effects of the studies on the hybrid layer for dentin adhesion.

Keywords: Adhesion; dentin proteininization; matrix metalloproteinases

Sorumlu Yazar*: Nihan Cevlek, Çocuk Diş Hekimliği ABD, Gazi Üniversitesi Diş Hekimliği Fakültesi, Ankara/TÜRKiYE

E-posta: nihan_cvlk@hotmail.com

Gönderim: 03.01.2020 Kabul: 26.04.2020

ORCID: 0000-0001-5056-6457

Doi: $10.18663 /$ tjcl.667021 


\section{Giriş}

Diş çürüğü dişin sert dokularında yıkıma neden olan, kronik, bulaşıcı ve multifaktöriyel bir hastalıktır. Çürük sonrası oluşan sert doku yıkımlarının tamiri için çürük dokunun uzaklaştırılması (kavite hazırlığı) ve kavitenin restoratif bir materyal ile yeniden şekillendirilmesi gerekmektedir. Kavite hazırlığında uzun yıllar boyunca benimsenmiş "korumak için genişlet" prensibi adeziv diş hekimliğinde görülen gelişmeler ile birlikte yerini yalnızca çürük dokusunun kaldırıldığı"minimal invaziv tedavi” prensibine bırakmaya başlamış, bu bağlamda adeziv sistemlerin başarısı ve adezyon kavramı ön plana çıkmıştır [1].

\section{Adezyon}

Adezyon (bağlanma) kelime olarak latincedeki "adhaerere" kelimesinden gelmektedir. Farklı moleküller arasındaki çekim kuvveti "adezyon"; aynı moleküllerin birbirleri arasındaki çekim kuvveti ise "kohezyon" olarak tanımlanır. Adezyonu oluşturan maddeye "adeziv" ; adezivin uygulandığı maddeye ise "adherent" adı verilir. Adezyon için, adeziv ve adherent arasında tam bir temas olması gerekmektedir [2].

\subsection{Adezyon Türleri}

Mekanik Adezyon: Adezivin, adherent veya substrat yüzeyindeki girintili ve çıkıntılı düzensiz yüzeylere kilitlenmesi olarak tanımlanır. Bu kilitlenmede geometrik ve reolojik etkenler söz konusudur. Yüzey pürüzlülüğü veya mikroskobik olarak oluşan porözitenin neden olduğu mekanik adezyon geometrik etkenlere; materyalin akışkanlık özelliğinden dolayı bir çıkıntı etrafına akması ve büzülerek tutunması ise reolojik etkenlere örnektir [2].

Fiziksel Adezyon: Bu tür adezyon birincil ve ikincil kuvvetlerin etkisi ile oluşur. Birincil kuvvetler; iyonik, kovalent ve mekanik bağlar olmak üzere üç farklı şekildedir. İkincil kuvvetler ise hidrojen bağları, Van der Walls, Keesom dipol interaksiyon, London dispersiyon kuvvetleri ve Debye dipol indüksiyon kuvvetleridir [3]. Yüzey düz ve kimyasal olarak farklı ise oluşan tek bağlantı tipi fiziksel olmaktadır [4].

Kimyasal Adezyon: Atomların ara yüzeyde adezivden aderente doğru geçtiği bağlantı tipidir. Adeziv ve adherentin kimyasal ve fiziksel farklılıklarından dolayı, bu bağlanma tipinin genel bağlanma kuvvetine katkısı oldukça düşüktür [4].

\section{Diş Hekimliğinde Adezyon}

1955 yılında ilk kez Buonocore tarafından demonstrasyonu yapılmış ve \%85'lik fosforik asitle mineye asit-etch uygulayarak rezin-mine bağlanma gücü artırılmıştır. Buonocore; asitlemenin basitçe rezin retansiyonu için ulaşılabilir mikroskopik yüzey alanını artırdığına inanmaktadır. Ancak; onun öğrencilerinden John Gwinnett (elektron mikroskopist) asitlenmiş mine yüzeyi ve rezin infiltrantın arayüzeyini daha yakından incelemiştir. Adeziv rezinlerin asit-etch uygulanmış mine prizmalarına penetre olabildiğini ve rezinin apatit kristallerini sarmalladığı alanda yapının asite daha dayanıklı hale geldiğini rapor ederek ilk gerçek hibrid tabaka tanımlanılmıştır [5]. Nakabayashi ve diğerleri ise; asitlenmiş dentinde açığa çıkan kollajen fibrillerin rezin infiltrasyonu ile desteklendiğini göstermiş ve bu yeni biyokompozit yapıyı "hibrid tabaka" olarak adlandırmışlardır. Böylece diş hekimliğinde kullanılan dental adeziv sistemlerin gelişimi başlamıştır[6].

\subsection{Mineye Adezyon}

Minenin inorganik içeriğinin fazla olması sebebiyle, asitlere karşı daha dirençli bir yapıya sahiptir ve yüzey enerjisi daha yüksektir.Laboratuvarsonuçlarınagöre,fosforikasituygulaması sonrasında, kompozitin mineye makaslama bağlanma kuvveti genellikle $20 \mathrm{MPa}$ 'nın üzerindedir[7]. Bu bağlanma kuvveti birçok restorasyon için yeterli retansiyonu sağlamaktadır ve mikrosızıntının gerçekleşmesini önlemektedir. Mine yüzeyine asit uygulanması, farklı düzeylerde prizmatik ve interprizmatik mineral kristallerini ortadan kaldırarak mikroskobik pürüzlülük sağlar. Aynı zamanda asit uygulaması sonrasında minenin yüzey geriliminde düşüş gözlenir ve yüzeyin ıslanabilirliği artar. Bu şekilde oluşan mikroporözitelere rezinininfiltrasyonu daha kolay bir hal almaktadır[1].Temel olarak minenin asitle pürüzlendirilmesi sonrasında oluşan porözitelere rezinin infiltre olması ve açığa çıkan hidroksiapatit kristallerinin monomerlerle sarılmasıyla minede mikromekanik adezyon gerçekleştiği bildirilmiştir [8].

\subsection{Dentine Adezyon}

Mineden farklı olarak dentinin nemli bir dokuya sahip olması, adezyon açısından en büyük güçlüğü oluşturmaktadır[9]. Dentin dokusunda tübüllerin içerisinde bulunan sıvı pulpanın hücreden fakir tabakasındaki kapiller damarlardan gelen plazma sıvısıdır. Dentine bağlanmada rol oynayan en kritik faktör dentin sıvısının miktarıdır. Dentin sıvısı miktarı dentinin derinliği, lokalizasyonu, dentin tübüllerinin yoğunluğu ve çapına göre değişir [1].

Nemli bir doku olmasının dışında dentine adezyonda rol oynayan diğer etkenler; dentinin içeriği (dentin tübüllerinin yoğunluğu, çapı, peritübüler ve intertübüler dentin oranı), kalınlığı ve yapısına bağlı olarak dentinin değişen geçirgenliği (demineralize ya da sklerotik dentin), yaşı, smear tabakası ve hibrid tabakanın varlığı ya da yokluğudur [2]. 


\subsubsection{Smear Tabaka}

Diş sert dokuları, bir frez ya da başka bir alet ile prepare edildikten sonra diş yüzeyinde kalan organik ve inorganik bileşenler yüzeyde "smear tabakası" adı verilen bir debris oluşturur. Yapısında inorganik dentin parçacıkları, denatüre kollajen parçacıkları, hidroksiapatit kristalleri, odontoblast uzantıları, kan hücreleri, bakteri ve tükürük bulunmaktadır[10]. Bu tabaka dentin kanallarının ağzında toplandığında "smear" tıkaçları denilen yapıları oluşturur. Smear tabakası ve tıkaçları dentin için doğal bir bariyer görevi görerek dentinal sıvının hareketini \%80-90 oranında, diffüzyonunu ise \%25-30 oranında azaltmaktadır [11].

Smear tabaka asit uygulaması ile kolaylıkla uzaklaştırılabilmektedir ancak mekanik olarak kaldırmak mümkün olmamaktadır. Smear tabakası ve smear tıkaçlarının asidik solüsyonlar ile uzaklaştırılması, açığa çıkan dentin yüzeyine sıvı akışını artırmakta ve dentine bağlanmayı negatif yönde etkilemektedir[9].

Dentin tübüllerinin içerisindeki sıvı hareketlerini ve dentin geçirgenliğini önemli derecede azaltan smear tabakası dentine çok zayıf bağlanmakla birlikte (5 Mpa) günümüz adezyon stratejilerinde bu bağlanmanın bir anlamı yoktur[2].

\subsubsection{Hibrid Tabaka}

Günümüz adeziv restoratif materyallerin temel bağlanma mekanizması hibrid tabakanın oluşumuna dayanmaktadır. Hibrid tabaka ilk olarak Nakabayashi(1992) tarafından demineralize dentin yüzeyine ve kanallarına monomerlerin infiltrasyonu ve sonrasında polimerizasyonu olarak tanımlanmıştır. Diş sert dokularında oluşan mikromekanik bağlanma tabakasına, hibrid tabakası ya da rezin ile güçlendirilmiş bölge adı verilmektedir [12].

Hibrid tabakası oluşumunda asit uygulaması sonrası demineralize edilmiş dentinin geçirgenliğini koruması en önemli etkendir. Hibrid tabaka ile ilgili yapılan birçok çalışma sonucunda birçok adeziv sistem ile elde edilen bu tabaka kalınlığının 1-5 mikrometre arasında değiştiği bildirilmiştir. Hibrid tabakanın kalınlığını etkileyen bir diğer faktör de dentinin asitlenmesi sonrasında oluşan demineralizasyonun derinliğidir. Oluşan demineralizasyon miktarı dentinin mineral yoğunluğu, kimyasal içeriği ve morfolojik özellikleri ile de değişebilmektedir[1]. Fakat yapılan bir çalışmada dentine bağlantı kuvveti ve hibrid tabakasının kalınlığı arasında bir ilişki bulunmadığı bildirilmiştir [13].

Dentine bağlanmanın temelinde, asit uygulamasıyla açığa çıkarılan kollajen fibrillere tamamen infiltre olan adeziv monomerlerin varlığıyla oluşan hibrid tabaka sayesinde yüksek kaliteli arayüz elde edildiği kabul edilmektedir. Modern adeziv sistemlerde genellikle yerleştirildiklerinden hemen sonra yüksek kalitedemarjinal sızdırmazlık ve bağlanma gücü başarısı rapor edilmekle birlikte, sonuçların in-vitro ve in-vivo olarak birkaç ay içinde bozunmaya başladığı bildirilmektedir[14].

Hibrid tabakanın temelini oluşturan expoz kollajenin enzimatik ve hidrolitik bozunması fiziksel ve kimyasal çeşitli faktörlere bağlıdır. Araştımacılar, hibrid tabakanın bileşenleri bozunmaya başlar başlamaz tabaka içerisinde su ile dolu kanallar oluştuğunu ileri sürmüşlerdir. Bu kanallar oral ve dentinal sıvıların erişmesine izin vererek tabakanın daha fazla bozunma olasılığını artırır. Bu bağlamda hibrid tabakanın güçlendirilmesi fikri ortaya çıkmıştır [15].

\section{Adezyon Kapsamında Hibrid Tabakaya Yönelik Çalışmalar}

\subsection{Matrix Metalloproteinazların İnhibe Edilmesi}

Matriks-metalloproteinazlar (MMPs) ilk olarak 1962 yılında bulunmuştur. Endopeptidaz ailesinin bir üyesi olan MMPs'ler ekstraselüler matrikste lokalizedirler[16,17]. Fizyolojik olarak MMPs hidroliz yoluyla, kollajen öncelikli olarak, degrade proteinler tarafından remodele edilen düzenli dokuya katılır. MMPs'lerin tükrük, dişeti oluğu sıvısı ve dentinde mevcut olduğu bulunmuştur. Dentinde tüm 23 insan MMPs'lerinden $-2,-3,-8,-9$ ve -20 MMPs'leri gösterilmiştir [18].

MMPs'ler, dentinogenezis sırasında odontoblast tarafından üretilir ve daha sonra inaktif şekilde dentin içine katılırlar. Asidik pH değeri 4,5'in altındayken MMPs'ler aktive olur ve tam fonksiyonel enzim haline gelirler $[16,17]$. Dentin-pulpa kompleksi ile ilgili olduğu kadar MMPs'lerin demineralizasyon öncesinde ve sırasında hücre dışı matriks organizasyonunda ve peritübüler dentin oluşumunda da rol aldığı varsayılmaktadır Bununla birlikte; bugüne kadar matür dentinde MMPs'lerin çok az fonksiyonu kesin olarak bilinmektedir [19].

Demineralize dentin; bağlı matriks metalloproteinazlar (-2,$3,-8,-9,-20)$ ve katepsinler içermektedir ve inaktif haldeki bu yapılar asit\&etch işlemi ile aktive olarak hibrid tabakanın iç katmanlarına yavaşça degrade olur[5].

Etch\&rinse tekniği ile oluşturulan bir rezin-dentin bağı 6 ay ile $5 y ı l$ içerisinde önemli ölçüde gücünü kaybeder. Bu; sekonder çürük, aşırı duyarlılık ve restorasyonların kaybına yol açabilir. Adezyon gücünün azalması ile ilgili, dentin kollajen ağının 
yapısı ve MMPs'lerin ağırlıklı faktörler olduğu belirtilmiştir[20]. \%37'lik fosforik asit kullanılarak aşındırma işlemi ile kolajen fibriller açığa çıkar ancak buraya uygulanan adeziv bonding ajanlarının infiltrayonu yetersiz olabilir. Sonuç olarak, hibrid tabakanın altında non-infiltre kollajen açık-desteksiz bir tabaka halinde kalır. Bu non-infiltre kolajen aktif MMPs içerir ve bu enzimlerin yapılan işlemler sonrası aktive olması sonucunda kolajen bozulabilir. Sonuç olarak hibrid tabaka parçalanır ve bağlanma kuvveti giderek azalır [20]. Bu bağlamda araştırmacılar MMPs'leri inhibe edecek materyal ve yöntemlere gereksinim duymuşlardır.

MMPs aktivasyon inhibitörleri şöyle sıralanabilmektedir; etilendiamin tetraasetik asit (EDTA), klorheksidin(CHX), carbodiimide, kitosan, çinko oksit(ZnO), tetrasiklin, galardin, proantosiyanidinler, epigallotechtin-3-Gallate (EGCG), quaternary amonyum tuzları.

EtilendiaminTetraasetikAsit:Etilenediamin tetraasetikasit(EDTA) kök kanal sisteminin mekanik enstrumentasyonu sırasında ve irrigasyonunda en yaygın biçimde kullanılan ajanlardan biridir. EDTA, dentin yüzeyinden smear tabakayı arındırır fakat etkisi kendi kendine sınırlayıcı bir özellik taşımaktadır.

MMPs'lerin katalitik hidroliz faaliyetlerinde üçüncül yapı ile bağlanmaları için çinko iyonları ve kalsiyum gerekmektedir. Asitlenmiş dentinde açığa çıkan katyonlar ile EDTA şelasyon yaparak MMPs'lerin inaktivasyonunu sağlamaktadır. Bazı araştırmacılar açıktaki MMPs' leri inaktive edecek bir prosedür olarak mine ve dentin yüzeyine $0,5 \mathrm{ml}$ EDTA kullanımı koşulunu savunur[21]. EDTA'nın "etching" etkisi birkaç dakikada dentinin 1-2 $\mu \mathrm{m}^{\prime}$ lik kısmını etkileyecek kadar zayıftır. Araştırmalarda \%32-37 fosforik asitle 15sn. asitlemenin ardından asitlenmiş dentinin anti-MMPs şelatörleri ile tedavi edilmesi önerilmektedir. Asitlenmiş dentinde MMPs'leri inhibe edebilecek diğer olası şelatörler; 1,10-fenantrolin, etilen diamin tetrafosfonik asittir [22].

EDTA'nın 1 ile 5 dakika uygulanması insan dentininde MMP-2 ve MMP-9 aktivasyonuna karşı önleyici bir etki göstermektedir. Sonuçlar fosforik asit ve başka asit tipleriyle karşılaştırıldığında dentin-adeziv bağlanma gücünde bir artış sergilemiş̧tir. Aynı zamanda EDTA'nın bu konudaki uzun dönem takip çalışmalarında dentin-adeziv arayüzündeki adezyonu koruduğu gösterilmiştir. EDTA'nın dezavantajı ise, suyla durulandıktan sonra dentin yüzeyinden tamamen kaybolabilmesidir. MMPs'lerin aktivitesini baskılayacak artık EDTA ortamda hiç kalmayabilir [23.24].
Klorheksidin: Klorheksidin(CHX) oral bakterilere karşı geniş bir aktivite yelpazesine sahip yaygın kullanılan bir antimikrobiyal ajandır. CHX yakın zamanda MMPs'lerin inhibe edilmesi yoluyla hibrid tabakayı koruyacak bir proteaz inhibitörü olarak incelenmiştir. Dentinal kollajen fibrillere rezin tam olarak infiltre olamazsa MMPs'ler sayesinde hibrid tabaka bozunmaya uğrayabilir. Dentine asit uygulandıktan sonra, CHX içeren su bazlı primer kullanılmasıyla dentine bağlanma gücünün ve hibrid tabakanın bütünlüğünün zaman içerisinde korunduğu rapor edilmektedir[25].

Yapılan bir çalışmada etch\&rinse sistemlerde terapötik astar olarak klorheksidin kullanımı ile bu enzimlerin inhibe edilmesi amaçlanmıştır. Sonuç olarak bondun dentine adezyonunun uzun bir süre için muhafaza edildiği rapor edilmiştir. MMPs' lerin yanısıra adeziv bond kalitesini etkileyen diğer faktörlerin genellikle bir dereceye kadar etkili olduğu ve CHX ile MMPs inaktivasyonu nedeniyle daha uzun süreler için bağlanmanın kararlı kaldığı bildirilmektedir [25].

Carbodiimid: Carbodiimid (1-Etil-3-[dimetilamino propil]) ve carbodiiimid hidroklorür(EDC) stabil syanamid izomerlerdir. EDC ile dentine bağlanmanın stabilitesi ve onun çapraz bağlanma kapasitesini geliştirmek mümkündür. Kollajenin bu mekanizması rezidüel glutamik ve aspartik karboksilik asit grupları arasında çapraz bağlama aktivasyonunu içerir[26].

EDC, dentin matrixinin yüksek mekanik özellikleri ve kollajenin yavaş parçalanma oranları nedeniyle, arayüz stabilitesini artırmak için büyük bir potansiyele sahiptir. Bu yüzden EDC'nin MMPs'leri uzun vadede etkisiz hale getirdiğini söylemek mümkündür[27].

Kitosan: Kitin'in deasetilasyonu ile elde edilen lineer bir aminopolisakkarittir. B2 vitamini yani riboflavin ise, pentoz şeker olan ribitol ve lumikromdan oluşur. Kitosan ve riboflavin ile adeziv substratın modifikasyonu sağlanarak MMPs'lerin hidrolitik ve kollajenolitik degradasyonuna karşı kollajenin mekanik özellikleri ve demineralize dentinin stabilitesi arttırılmaktadır. Fakat kitosan içeriği, interfibriler alanlarda majör obliterasyon artışına kademeli olarak izin verir bu da olumsuz bir bağlanma ile sonuçlanabilir[28].

ZnO: Kenetleyici özelliklere sahip sentetik peptidomimetik olan bu inhibitör, MMPs'lerin ve katalitik alanın aktif bölgesinin inhibisyonunda kullanılabilir. Dental adezivlere ZnO parçacıklarının eklenmesi, minör dentin kollajen degradasyonu ve rezin-dentin bağında artan dayanıklılığa sebep olarak adeziv bağlanma etkinliğinin uzun süre korunacağı bildirilmektedir[29]. 
Tetrasiklin: Her ne kadar tetrasiklin'ler yaygın olarak protein sentezine müdahale ettikleri ribozomal seviyede hareket eden geniş yelpazeli antibiyotikler olarak bilinseler de aynı zamanda inflamasyon, hücre çoğalması ve anjiyogenezis gibi başka biyolojik hareketler de ortaya koyarlar[30].

Tetrasiklinler ve onların analogları bu antibiyotiklerin antimikrobiyal özelliklerinin mekanizmalarından bağımsız olarak MMPs'leri baskılarlar. Tetrasiklinlerin ve analoglarının $\mathrm{Ca}+2$ ve $\mathrm{Zn}+2$ 'ya bağlanma bölgelerinin kısmen MMPs'lerin hücre dışı aktivitesini baskılamaktan sorumlu olduğu iddia edilse de, ekstraselüler matrikste ve hücre içi bölgede de antimikrobiyal olmayan birçok mekanizma ile terapötik özellik göstermekte oldukları bilinmektedir [31].

Günümüzde üç tetrasiklin grubu mevcuttur; tetrasiklin ve doğal ürünler, yarı sentetik tetrasiklin komponentleri ve kimyasal açıdan modifiye olmuş tetrasiklin. Minosiklin ve doksisiklin, yani sentetik tetrasiklinlermedikal ve dental uygulamalara sahiptir[31].

Tetrasiklin ve yarı sentetik formları, doksisiklin, MMPs'lerin kollajen degradasyonu aktivitesini inhibe etme yeteneğine sahiptir[32]. Dentin yüzeyi asitleme prosedüründen sonra kollajenaz ve jelatinazı inhibe edebilme özelliğinden dolayı \% 2'lik doksisilin sulu çözeltisi ön tedavi olarak kullanımı gündemdedir[33].

Galardin: Galardin MMPs substratlarının bir moleküler taklidi olarak tasarlanmış güçlü ve geniş spektrumlu hidroksamik tipinde sentetik MMPs inhibitörüdür. Çinko atomuna bağlanan MMPs'lerin aktif bölgesine girerek inhibisyon etkisi gösterir. Galardin birkaç MMPs'a karşı aktiftir.

Galardinin dentin MMPs'leri üzerindeki baskılayıcı etkisi analizlerle teyit edilmiş, bağlanma gücünü tehlikeye atmadan MMP-2'nin ve MMP-9'un aktivitesini tamamen önlendiği gözlemlenmiştir. Yapılan bir çalışmada, bağlanma yüzeyi 0,2 ml galardin-su solüsyonu ile muamele edilmiştir. Bağlanma gücünde yavaşlamış bir azalma ve nanosızıntı miktarında düşüş gösterilmekle birlikte bu durumlar tamamen bloke edilememiştir. Bu çalışmanın 1 yıllık takibi sonrasında ise adezyon gücünde \%27'lik bir azalma olduğu rapor edilmiş ; ve bu sonucun kontrol gruplarında ölçülen \%45'lik azalmadan anlamlı derecede daha az olduğu bildirilmiştir[25].

Proantosiyanidin: Flavonoid bileşimlerin kompleks bir alt grubu olan proantosiyanidinler (PA); çok çeşitli meyve, sebze, çiçek, fındık, kabuk ve tohumlarda bulunmuştur[34]. Daha çok üzüm çekirdeği ekstresi olarak bilinen ve çapraz bağlayıcı olan bu maddenin MMPs'leri de inhibe ettiği gösterilmiştir[35].PAkullanılan adeziv sistemler ile saf adeziv model karşılaştırıldığında, PA eklenmiş sistemlerin biyolojik bozunmaya karşı direnci artırdığı ve enzimatik bozunmadan sonra hibrid tabakanın daha iyi korunmasını sağladığı bulunmuştur. PA'nın kollajenin çapraz bağlanmasına etkili olduğu ve 10 sn. gibi kısa bir süre içinde biyolojik kararlılığı artırabildiği bildirilmektedir. Demineralize dentinde PA 'nın ön tedavi olarak kullanılması klinik olarak mümkün ve geçerli bonding sistemlerin dayanıklılığını artırmak için umut verici bir yaklaşımdır[36].

PA'nın; sıçanlarda mandibular kondilde kemik formasyonunu desteklediği, demineralize dentin sertliğini artırdığı ve yapay kök çürüklerinin ilerlemesini inhibe ettiği gösterilmiştir[37].

Çinko metakrilat: Çinko metakrilat(ZM) bir metalloproteinaz inhibitörüdür ve diğer metakrilat monomerler ile kopolimerize olabilir. Yapılan çalışmada ZM, MMP-2'yi inhibe etmiştir.Bu nedenle ZM ilavesinin adezyon gücüne etkisinin olabileceği kanısına varılmıştır[38].

Epigallotechtin-3-Gallate: EGCG, matriks-metalloproteinaz molekülünü bozarak MMP-2 ve MMP-9'un aktivitesini baskılamaktadır.

Diş hekimliğinde EGCG, bir adezive ilave edildiğinde Streptococcus mutans'ın büyümesi üzerindeki baskılayıcı etkisinden ayrı olarak periodontal hastalıkta osteoklast oluşumunda yer alan MMP-9'un aktivitesini ve salınımını engelleyebildiği rapor edilmiştir. Aynı zamanda MMP'leri baskılayarak dentinin erozyonunu-aşınmasını azalttığı bildirilmektedir. Anti-MMP özellikleri yüzünden EGCG içeren adezivler rezin-dentin bağının dayanıkılığını arttırma potansiyeline sahip olabilirler; fakat bu henüz tam olarak araştırılmamıştır[25].

Quarternary Amonyum Tuzları: Dört elementli amonyum bileşikleri antimikrobiyal özelliklere sahiptirler ve dental rezinlere eklenebilirler. Fakat suda çözülebilir moleküller oldukları için adeziv arayüzünden ayrılabilirler. Dört elementli amonyum molekülleri rezin matriksinde hareketsiz hale geldiklerinde bakteriyostatikaktiviteye sahipolabilmektedirler.

12-methacryloyloxydodecylpyridinium bromide (MDPB) gibi dört elementli amonyum metakrilat kullanılmasının avantajlarından biri onların adeziv monomerlerle birlikte polimerize olabilmeleridir. Clearfil Protect Bond (Kuraray Noritake Dental Inc. Osaka Japonya) MDPB'yi bileşimine dahil eden ilk ticari dentin adezivdir[39]. 
Yapılan bir çalışmada rezin-dentin bağlarının bozunması Clearfil Protect Bond veya Clearfil SE Bond (çok benzer kompozisyona sahip adeziv, ancak MDPB den yoksundur) kullanılarak değerlendirilmiş, sonuç olarakClearfil SE Bond'da bozunma paterni gözlemlenirken Clearfil Protect Bond'da bulgulanmamaktadır. Bu da MDP içeren adeziv kullanımının hibrid tabakayı desteklediğini göstermektedir[40].

Aynı zamanda benzalkonium klorid (BAC) molekülünde dört elementli amonyum grubu içeren bir antimikrobiyal maddedir. Bu madde birkaç yıl bir fosforik asit jele dahil edilmiş fakat bu jelin kullanılması mine ve dentine bağlanma gücünü etkilememiştir. Yakın zamanda BAC'nin anti-MMP özellikleri MMP-2, 8 ve 9'a karşı test edilmiştir. Sonuçlar bu maddenin MMP-2; 8 ve 9'u baskılama potansiyelini göstermiştir[40].

\subsection{Kollajenin Mekanik Özelliklerini Artırma}

Çapraz bağlantı, asitlenmiş dentin matriksinde kollajen degradasyonunun kararlıığını ve direncini arttırmada bir potansiyel metot olarak kabul edilir. Adeziv uygulanmadan önce, kollajen fibrillerinin çapraz bağlantı derecesinde artış, bağlantının dayanıklılığını arttırmasıyla sonuçlanabilmektedir. Kollajenin bozunma gücünü proteaz kullanımı sayesinde arttırmaktan başka, bazı çapraz bağlantı ajanlarının anti-MMPs özelliklere sahip oldukları gösterilmiştir. Bununla beraber, MMPs'ları ve sistein katepsinleri inaktive etmede çapraz bağlantı ajanları kullanılmasının önemli dezavantajlarından biri; arzu edilen terapötik etkiyi elde etmede ihtiyaç duyulan uygulama/ aktivasyon zamanının klinik yapılabilirlik dahilinde olmamasıdır. Başka bir dezavantaj ise kötü mekanik özelliklere sahip suca zengin kollajen matriksinin hibrit tabaka içinde oluşmasıdır[42]. Yakın zamanda fiziksel metodlar, özellikle ultraviyole radyasyonu, diş hekimliğinde ve oftalmolojide denenmiştir. Ultraviyolenin (UVA) aktive ettiği riboflavin'in bağlanma gücünü arttırdığı, adeziv ara yüzeyini dengelediği ve dentin MMPs'lerinin aktivasyonunu önlediği gösterilmiştir. Riboflavin, adeziv diş hekimliğinde önemli bir potansiyele sahiptir çünkü UVA mavi ışık tarafından aktive olan,uygulanması kolay ve biyouyumlu bir materyaldir. UVA'nın aktive ettiği riboflavinin, dentin kollajeninin mekanik özelliklerini, kararlılığını, bozunma direncini arttırdığı ve kollejenolitik sindirime dirençli hale geldiği gösterilmiştir[43].

Dentindeki endojen MMPs'ların inaktivasyonu için diğer bir yaklaşım, asitlemeden hemen sonra onların peptid zincirlerinin çapraz bağlanmasıdır. Bu onların enzim aktivitesi için gerekli olan moleküler hareketliliği kaybetmesine neden olur [44].
"Gluteraldehit"invitroolarak 10yıldırbirçaprazbağlamamaddesi olarak kullanılmaktadır. Bununla birlikte residüel gluteraldehitin tedavi edilen dokudan yıkanarak uzaklaştırılmasının sitotoksik olduğu gösterilmiştir.\%5 gluteraldehit, \%35 HEMA, \%60 su karışımlarından oluşan adeziv sistemler (Gluma Desensitizer, Heraeus Kulzer); dentin desentizerleri olarak bu amaçla kullanılmaya devam etmektedir[45].

Bir çalışmada rezin-dentin bağlantısında çekme dayanımıüzerinde üç farklı çapraz bağlama ajanı; gluteraldehit(GD), üzüm çekirdeği ekstresi(PA), Genipin(GE) etkisini araştırmak amaçlanmıştır. Dentin matrixinde kimyasal modifikasyon GD ve PA tarafından en iyi şekilde düzenlenmiş ve bağlanma gücünü anlamlı olarak artırdıkları rapor edilmiştir[46].

\subsection{Deproteinizasyon}

Asit uygulaması ile dentin demineralizasyonu karışık ve yüzeysel bir prosedür olmakla birlikte dentin dokusunda smear tabakası kaldırılarak 3-7,5 $\mathrm{m}$ arasında bir kollajen örgü açığa çıkmaktadır[47]. Klinik olarak, uygun bir dentin bonding için ideal senaryo demineralize dentinin tüm uzatılarına homojen olarak rezinin penetrasyonu, solvent/su eliminasyonu ve rezin monomer polimerizasyonu sonucunda hibrid tabaka oluşmasıdır. Ancak bu prosedür teknik hassasiyet gerektirmekte ve klinik başarıyı oldukça etkilemektedir. Araştırmacılar hibrid tabaka varlığının dentine adezyon açısından dezavantajları olabileceğini bildirmişlerdir.

Nanosızıntı terimi 1995 yılında Sano tarafından marjinal boşlukların yokluğunda var olan spesifik bir sızıntı olarak tanımlanmıştır. Bu sızıntı hibrid tabakanın altında adeziv rezinin tamamen infiltre olmadığı ve polimerizasyonun zayıf olduğu submikron poroziteler yoluyla lateral olarak oluşur[48]. Ayrıca bağlanmayı etkileyen hibrid tabakanın altındaki nonkapsüle kollajen hidrolitik bozunmaya hassastır ve bond stabilitesini tehlikeye atabilir. Araştırmacılar asit-etch'den sonra açığa çıkan kollajenin çeşitli ajanlarla uzaklaştırılmasının (deproteinizasyon) dentin dokusunda hibrid tabaka oluşumundan bağımsız, mineye benzer mikromekanik adezyona olanak sağlayabileceğini bildirmişlerdir. Bu bağlamda deproteinizasyonun dentin adeziv prosedürlerinde teknik hassasiyeti azaltabileceği; mikrosızıntı, makaslama ve çekme kuvvetlerinde süregelen artış sağlayabileceği öne sürülmektedir[49].

Dentinde kollajen yapının uzaklaştırılması için kollajenaz gibi deproteinize edici enzimler ve ajanlar kullanılmaktadır. $\mathrm{Bu}$ amaçla kullanılan en genel ajan olan sodyum hipoklorit( $\mathrm{NaOCl})$, organik materyalleri çözebilen nonspesifik bir proteolitik ajandır. Bu ajan ile tedavi edilen dentin, 
minerallerden zengin olmakla birlike uzun vadede daha stabil arayüzler oluşturabilen bir yapıya sahiptir. Sodyum hipoklorid ile yapılan deproteinizasyonun adeziv tabakasının bozunum riskinin azaltacağı düşünülmektedir. Ancak bu varsayımı güçlendirmek için daha ileri çalışmalar gereklidir[49].

Yapılan bir çalışmada, farklı dentin bölgelerinde adeziv sistemlerin bağlanma gücüne $\mathrm{NaOCl}$ ön tedavisinin değerlendirilmesi amaçlanmıştır. 40 insan dişi farklı adeziv sistemler (Adper Single Bond 2,Clearfil SE Bond, Adper SE Plus, G-Bond) kullanılmak üzere rastgele, ön işlemler (kontrol ve $\mathrm{NaOCl}$-deproteinizasyon) ve dentin bölgeleri (proksimal, yüzeysel oklüzal[SO] ve derin oklüzal[DO]), olmak üzere gruplara ayrılmıştır. Her bir örneğin oklüzal ve proksimal yüzeylerine silindirik kavite hazırlanmıştır. Deproteinizasyon için adeziv sistemlerin uygulanmasında önce dentine 60 saniye $\% 10$ $\mathrm{NaOCl}$ uygulanmıştır. Her numuneden 2 oklüzal ve 1 proksimal dilim elde edilmiş ve push-out testi ile fraktür biçimleri analiz edilmiştir. Adeziv sistemler ve dentin bölgesinde bağlanma gücü açısından istatiksel olarak anlamlı bir fark bulunmamıştır ve $\mathrm{NaOCl}$ ile yapılan ön tedavi, bağlanma kuvveti değerlerini önemli ölçüde etkilememiştir. Öte yandan iki aşamalı self-etch adeziv sistemlerin kullanıldığı dentin yüzeylerinde en yüksek bağlanma gücü sonuçları rapor edilmiştir[50].

$\mathrm{NaOCl}$ ve $\mathrm{Nd}$ YAG lazer ile deproteinizasyonu yüzey tedavilerinin dentin permeabilitesinde longtudinal etkileri halen araştırılan bir konudur. Yapılan bir araştırmada dentin geçirgenliği, permeabilite cihazı ile dentin sıvı akışı ölçülerek değerlendirilmiştir. 80 tane sığır dentin numunelerinin smear tabakası varlığında ve EDTA ile smear tabakasının yok edilmesinden sonra geçirgenlikleri ölçülmüştür. Daha sonra tedavi şekline göre 8 alt gruba ayrılmışlardır ( $n=10)$; Grup C- kontrol; Grup L- Nd:YAG lazer; Grup F- fluorid; Grup FLfluorid+Nd:YAG lazer; Grup A,-adeziv; Grup AL- adeziv+Nd:YAG lazer; Grup D-10\% NaOCl+adeziv; ve grup $\mathrm{DL}-\mathrm{NaOCl}+$ adeziv+Nd:YAG lazer. Nd:YAG lazer 60 m / darbe / 10 Hz / $47.7 \mathrm{~J}$ / cm (2) / 1 W ışınlanmış ve 60 saniye boyunca temas olmaksızın eli açık uygulanmıştır. Permeabilite, tedaviden 24 saat sonra ölçülmüştür. Numuneler 5 gün boyunca eroziv ( numunenin Coca-Cola içerisine günde 4 kez/90 sn. batırılması) ve abraziv (fırçalama) değişikliklere maruz bırakılmıştır. Günün ilk ve son eroziv ve abraziv değişiklikler sonrasında permeabilite tekrar ölçülmüştür. Sonuçlar istatistiksel olarak analiz edilmiş ve Tukey testleri yapılmıştır. Sonuç olarak; Grup FL ve grup A hariç tüm gruplar geçirgenliği azaltmıştır. Lazer ekspojürü ile kombine tedavilerde permeabilitede anlamlı bir azalma gözlenmiştir.
Adeziv ve Nd:YAG lazer birleşimi ise 24 saat sonrası en düşük geçirgenliği sağlamıştir. $\mathrm{NaOCl}$ ile deproteinizasyon ve $\mathrm{Nd}$ : YAG lazer birleşimi ise eroziv/abraziv uygulamalardan sonra en düşük geçirgenlik oranını göstermiştir[51].

Kalsiyum hipoklorid'in dentin deproteinizasyonu için kullanımı da güncel yaklaşımlar arasındadır. Bu konuda yapılan bir çalışmada $\mathrm{CaOCl}$ ile deproteinizasyonun asitlenmiş dentinin yüzey morfolojisi ve kompozit restorasyonların mikrosızıntısına olan etkisi ve deproteinizasyondan sonra dentinin yapısı analiz edilmiştir. Çalışmada, 40 tane 3. molar kullanılmışve dentin tedavisine göre 4 gruba ayrılmıştır: Tedavi öncesi ajan kullanılmamış, 30 sn süreyle \%10'luk $\mathrm{NaOCl} ; 30$ saniye süreyle $\% 10^{\prime}$ luk $\mathrm{CaOCl}$ ve 30 saniye süre ile $\% 15^{\prime}$ lik $\mathrm{NaOCl}$. Hazırlanan kaviteler aseton bazlı adeziv sistemler ve rezin kompozitlerle kapatılmıştır. Daha sonra 5000 devir ile ısı değişikliklerine maruz bırakılan ve 4 saat boyunca metilen mavisine daldırılıp $1 \mathrm{~mm}$ kalınlığında plakalar halinde kesilen örnekler, stereomikroskop altında değerlendirilmiş ve her grupta infiltrasyon derecesi(skor 0-3) tayin edilmiştir. 4 dişe gruplarına göre yüzey tedavisi uygulanmış ve dentin yapısal olarak analiz edilmiştir. Sonuç olarak deney grupları arasında anlamlı bir fark bulunamamıştır. $\mathrm{CaOCl}$ kompozit-dentin arayüzey morfolojisini değiş̧tirdiği gözlenmiş ve arayüzde kalsiyum artışına yol açtığı belirtilmiş fakat mikrosızıntı açısından diğer materyallerden farkı bulunmadığı rapor edilmiştir[52].

Asitlenmiş dentinin deproteinizasyonu için $\mathrm{NaOCl}$ kullanımının kırılgan zon oluşturma,sitotoksisite, kötü tad ve koku gibi çeşitli dezavantajları vardır. Bu dezavantajlar,deproteinizasyon için daha farklı ajanların araştırılması ile sonuçlanmıştır.

Aguilera ve arkadaşları, asitlenen ve asitleme sonrasında $\mathrm{NaOCl}$ ile deproteinize edilen dentinde tek aşamalı aseton bazlı adeziv sistem kullanılarak sağlanan dentin bağlantısını ultramorfolojik olarak ve bağlanma gücü açısından değerlendirmişlerdir. Adeziv sistem ve kompozit materyalin uygulanmasından sonra bağlanma kuvveti ölçümleri yapıldığında istatistiksel olarak gruplar arasında anlamlı bir fark bulgulanmamıştır. SEM ile yapılan ultramorfolojik incelemelerde ise asitleme sonrası $\mathrm{NaOCl}$ ile yapılan deproteinizasyon işleminin hibrid tabaka olmaksızın daha uzun ve yoğun rezin tagları oluşumunu sağladığı rapor edilmiştir. Bu sonucun tek aşamalı self-etch sistemlerinin kullanımında uygulanan \%5'lik $\mathrm{NaOCl}$ konsantrasyonu ve uygulama süresinden kaynaklanabileceği, konuyla ilişkin ileri çalışmaların yapılması gerekliliği vurgulanmaktadır[53].

Silva ve arkadaşlarınındentinde asitleme sonrası \%10 NaOCl 
ile deproteinizasyon yapılmasının 6 aylık dönemde bağlanma kuvvetine etkisini araştırdıkları çalışmada; deproteinizasyon işleminin adeziv sistemlerin dentine bağlanma gücünü arttırdığını bildirmektedir[54].

Torres ve arkadaşları; total etch adeziv sistemlerin \%10 NaOCl deproteinizasyonu ile kullanımının kompozit restorasyonları klinik başarısına etkisini araştırmışlardır. Amerika Birleşik Devletleri Kamu Sağlığı Hizmet Kriterleri doğrultusunda 5 yıllık klinik değerlendirme sonucunda 2 grup arasında istatistiksel olarak anlamlı bir farklılık oluşmadığı; ilave deproteinizasyon işleminin klinik olarak saptanabilir bir etki oluşturmadığı rapor edilmektedir[55].

Son çalışmalarda, hafif self etch adezivler için demineralizasyon ve rezin infiltrasyon derinliği, bağlanmanın bozulması faktörleri arasında bazı farklılıklar rapor edilmektedir. Dekalsifiye dentinde açığa çıkan kollajen fibriller ise etch\&rinse sistemler ve hidrofilik self etch adeziv sistemlerin her ikisinde de en zayıf nokta olarak karşımıza çıkmaktadır. Mekanik bozulma ve serbest radikallerin bulunması demineralize kollajen matriksteki degradasyon prosesini arttırabilmektedir. Bu reaktif serbest radikaller normal doku hasarının çeşitli formları ve yaşlanma ile ilişkilidir.

Oksidanlar (örneğin, hidroksil radikali) eşleşmemiş elektron içerirler ve oldukça reaktiflerdir.Böylece moleküler düzeyde protein yapılarına zarar verebilmektedirler. Genellikle antioksidan olarak adlandırılan birçok serbest radikal oksijenin reaktif formudur ve etkin temizleyicidir. Askorbatın okside formları nispeten kararlı olupdentin kollajenleri üzerindeasitlemenin oluşturduğu denatürasyon etkisini basklayarak kompozit-dentin adezyonun bozulmasına karşı koruma sağlamaktadırlar. Ön tedavi olarak NaOCI kullanımında dentinde bulunan düşük adezyon gücü askorbik asit veya askorbat ile tersine çevrilebilmektedir[56].

Deproteinizasyon yapmayı amaçlayan yeni ajanlar kollajenaz ya da bromelain enzimi gibi enzimlerinin içerir. Bromelain, meyve veya ananas kökünden ticari olarak elde edilen protein sindirici enzim grubuna ait bir proteolitik enzim (proteaz) 'dir. Proteazların fonksiyonu, protein hidrolizini katalize ederek amino asitlere ayrışmasını sağlamaktır[57].

Bromelain enziminin, $\mathrm{NaOCl}$ ile karşılaştırıldığında kolajen ağının kaldırılmasında ve bu bağlamda nanosızıntının azaltılmasında daha etkili olduğunu bildiren çalışmalar vardır. Öte yandan bond bağlanma gücünü artırmada etkinliğini gösteren bir çalışma henüz yapılmamıştır[58].

$\mathrm{Bu}$ nedenle, yapılan bir çalışmada bromelain enziminin deproteinizasyon etkisi ve adeziv sistemin uygulanmasından önce makaslama bağlanma gücü değerlendirilmesi için \% $5 \mathrm{NaOCl}$ ile karşılaştırılmıştır. Sonuç olarak; bromelain enzimi kullanımı bond gücünü önemli ölçüde etkilemiş, istatiksel olarakanlamlı farklılık yaratacak düzeyde en yüksek bağlanım gücü bromelain enzimi ile tedavi edilen grupta bulgulanmıştır[59].

\section{Sonuç}

Estetik restoratifmateryallerin vazgeçilmezlerinden olan adeziv sistemlerin yapısal özellikleri ve klinik uygulamalarının çok iyi bilinmesi restorasyonların başarısı için şarttır. Günümüzde etch and rinse ve self-etch sistem adezivlerinde çeşitli avantaj ve dezavantajları bulunmaktadır. Adeziv sistemlerin dezavantajlarını azaltabilmek adına sürekli iyileştirmelerin yapılması için araştırmalar devam etmektedir. Sürekli yeni teknolojilerin ve yaklaşımların geliştirilmesi ile birlikte özellikle yapısal içerikleri farklılık gösteren süt ve genç daimi dişlerle ilgili in-vivo ve in-vitro çalışmalara ihtiyaç duyulmaktadır.

\section{Çıkar çatışması / finansal destek beyanı}

Bu yazıdaki hiçbir yazarın herhangi bir çıkar çatışması yoktur. Yazının herhangi bir finansal desteği yoktur.

\section{Kaynaklar}

1. Kaya, T. Diş hekimliğinde kullanılan multimod, etch and rinse ve self etch adezivlerin süt ve daimi dişlerin sınıf I restorasyonlarında mikrosızıntı açısından karşılaştırılması. pHD Thesis, Başkent University Faculty of Dentistry, Department of Pediatric Dentistry, Ankara; 2014.

2. Dayangac, GB. Kompozit restorasyonlar. Ankara: Güneş Kitabevi Ltd. Şti; 2011.

3. Kiremitçi $A$, Altıncı $P$, Self etch adeziv sistemlerde güncel gelişmeler Bölüm1: Farklı özelliklerde diş sert dokularına bağlanma etkinliği. Hacettepe Diş Hekimliği Fakültesi Dergisi 2008; 32: 33-48.

4. Özkul S, Küçükeşmen Ç, Adezivler: Genel ilkeler ve tekniğin son durumu. Balıkesir Sağlık Bilimleri Dergisi 2012; 1: 164-168.

5. Pashley, DH, Tay FR, Breschi L et al. State of the art etch-and-rinse adhesives. Dental Materials 2011; 27: 1-16.

6. Nakabayashi N, The hybrid layer: a resin-dentin composite. Proceedings of the Finnish Dental Society Suomen Hammaslaakariseuran Toimituksia; 1992.

7. Van Meerbeek B, Inoue S, Perdiago J, Lambrechts P, Vanherle G. Enamel and dentin adhesion. Fundamentals of operative dentistry Second edition. Carol Stream, Quintessence International; 2001. 
8. Swift EJ, Perdigão J, Heymann HO. Bonding to enamel and dentin: a brief history and state of the art. Quintessence Int 1995 26: 95-110.

9. Roberson TM, Heymann HO, Swift EJ. Sturdevant's Art and science of operative dentistry. Fifth Edition. St. Louis, Missouri, Elsevier Mosby; 2005.

10. Van Landuyt K, De Munck J, Coutinho E, Peumans M, Lambrechts $P$, Van Meerbeek B. Bonding to dentin: Smear layer and the process of hybridization. Dental hard tissues and bonding interfacial phenomena and related properties Berlin: Springer; 2005.

11. Mjör IA; Pulp-dentin Biology in Restorative Dentistry. Mjör IA. Part 2 Initial reactions to preparation of teeth for restorative procedures. Quintessence International 2001; 32: 537-51

12. Dönmez N, Özer F. Hibrit tabakası, özellikleri ve hibrit tabakasında gözlenen mikroskobik oluşumlar. Gazi Üniversitesi Diş Hekimliği Fakültesi Dergisi 2007; 24: 57-62.

13. Perdigao J, May KN, Wilder AD, Lopes $M$, The effect of depth of dentin demineralization on bond strengths and morphology of the hybrid layer. Operative Dentistry 2000; 25: 186-94.

14. De Munck J, Van Landuyt $K$, Peumans $M$, et al, A critical review of the durability of adhesion to tooth tissue: methods and results. $J$ Dent Res 2005; 84: 118-132.

15. Tay FR, Pashley DH, Dental adhesives of the future. J Adhes Dent 2002; 4: 91-103.

16. Mazzoni A, Nascimento FD, Carrilho M et al. MMP activity in the hybrid layer detected with in situ zymography. J Dent Res 2012; 91: 467-72.

17. Thompson JM, Agee K, Sidow SJ et al. Inhibition of endogenous dentin matrix metalloproteinases by ethylenediaminetetraacetic acid. J Endod 2012; 38: 62-65.

18. Osorio R, Yamauti M, Osorio E, Ruiz-Requena ME, Pashley D, Tay F, Toledano M. Effect of dentin etching and chlorhexidine application on metalloproteinase-mediated collagen degradation. Eur J Oral Sci 2011; 119: 79-85.

19. Moon PC, Weaver J, Brooks CN. Review of matrix metalloproteinases' effect on the hybrid dentin bond layer stability and chlorhexidine clinical use to prevent bond failure. Open Dent J 2010; 4: 147-152.

20. Strobel S, Hellwig E, The effects of matrix-metalloproteinases and chlorhexidine on the adhesive bond; A literature review. Swiss Dent J 2015; 125: 134-40.

21. Sauro S, Mannocci F, Toledano M, Osorio R, Pashley DH, Watson TF. EDTA or $\mathrm{H} 3 \mathrm{PO} 4 / \mathrm{NaOCl}$ dentin treatments may increase hybrid layer resistance to degradation: A microtensile bond strength and confocal micropermeability study. J Dent 2009; 37:279-88.
22. Pashley DH, Agee KA, Wataha JC. Visco elastic properties of demineralized dentin matrix. Dent Mater 2003; 19:700-706.

23. Kanca J, Resin adhesive to wet substrate I: Adhesive to dentin. Quint Inter 1992; 23: 39-41.

24. Abate PF, Rodriguez VI, Macchi RL. Evaporation of solvent in one bottle adhesives. J Dent 2000; 28: 437-40

25. LiuY,Tjäderhane L, Breschi Let al. Limitations in bonding to dentin and experimental strategies to prevent bond degradation. J Dent Res 2001; 90: 953-68.

26. Bedran-Russo AK, Vidal CM, Dos Santos PH, Castellan CS. Longterm effect of carbodiimide on dentin matrix and resin-dentin bonds. Journal of Biomedical Materials Research Part B: Applied Biomaterials 2010; 94: 250-55.

27. Mazzoni A, Apolonio FM, Saboia VPet al. Carbodiimide inactivation of MMPs and effect on dentin bonding. J DentRes2014; 93: 263-68.

28. Fawzy AS, Nitisusanta LI, lqbal K, Daood U, Beng LT, Neo J. Chitosan/Riboflavin-modified demineralized dentin as a potential substrate for bonding. J Mech Behav Biomed Mater2013; 17: 278-289.

29. Toledano M, Yamauti M, Ruiz-Requena ME, Osorio RA. ZnOdoped adhesive reduced collagen degradationfavouring dentine remineralization. J Dent2012; 40: 756-65.

30. Marchetti C, Piacentini C, Menghini P. Morphometric computerized analysis on the dentinal tubuls and the collagen fibers in the dentine of human permanent teeth. Bull Group Int Rech Sci Stomatol Odontol 1992; 35: 125-29.

31. Wang Y, Spencer P, Walker MP. Chemical profile of adhesive/ cariesaffected dentin interfaces using Raman microspectroscopy. J Biomed Mater Res A 2007; 81: 279-86.

32. Stanislawczuk R, Costa JA, Polli LG, Reis A, Loguercio AD. Effect of tetracycline on the bond performanceof etch-and-rinse adhesives to dentin. Braz Oral Res 2011; 25: 459-65.

33. Longhi M, Cerroni L, Condo SG, Ariano V, Pasquantonio G. The effects of host derived metalloproteinases on dentin bond and the role of MMPs inhibitors on dentin matrix degradation. Department of Clinical Science and Translational Medicine University of Rome"Tor Vergata", Rome, Italy; 2015.

34. Ferreira D, Slade D. Oligomeric proanthocyanidins: naturally occurring O-heterocycles. Nat Prod Rep 2002; 19: 517-41.

35. La VD, Howell AB, Grenier D, Cranberry proanthocyanidins inhibit MMP production and activity. J Dent Res 2009; 88: 627-32. 
36. Liu Y, Chen M, Yao X, Xu C, Zhang Y, Wang Y. Enhancement in dentin collagen's biological stability after proanthocyanidins treatment in clinically relevant timeperiods. Dent Mater 2013; 29: 485-92.

37. Walter R, Miguez PA, Arnold RR, Pereira PN, Duarte WR, Yamauchi $M$. Effects of natural crosslinkers on the stability of dentin collagen and the inhibition of root caries in vitro. Caries Res 2008; 42: 263-68.

38. Henn S, de Carvalho RV, Ogliari FA et al. Addition of zinc methacrylate in dental polymers: MMP-2 inhibition and ultimate tensile strength evaluation. Clin Oral Investig 2012; 16: 531-36.

39. Hashimoto $\mathrm{M}, \mathrm{OhnoH}$, Kaga M. In vivo degradation of resindentin bonds in human sover 1 to 3 years. J Dent Res 2000; 79: 1385-91.

40. Armstrong SR, Vargas MA, Chung I. Resin-dentin interfacial ultra structure and microtensile dentin bond strengt hafterfive-year water storage. Oper Dent 2004; 29: 705-12.

41. Hashimoto M, A review-micromorphological evidence of degradation in resin-dentin bonds and potential preventional solutions. J Biomed Mater Res B Appl Biomater 2010; 92: 268-80.

42. Tay FR, Gwinnett AJ, Pang KM, Wei SH. Resin permeation into acidconditioned, moist, and dry dentin: A paradigm using water-free adhesive primers. JDent Res 1996; 75: 1034-44.

43. Jacobsen T, Söderhold KJ. Some effects of water on dentin adhesive. Dent Mater 1995; 11: 132-36.

44. Xu C, Wang Y. Collagen cross-linking by glutaraldehyde increases its biodegradation resistance in wet dentin bonding. Dent Mater 2010; 14: 11-18.

45. Pashley DH, Tay FR, Haywood VB, Collins MA, Drisko CL. Consensus-based recommendations for the diagnosis and management of dentin hypersensitivity. Compendium of continuing education in dentistry. 2008; 29: 1-35.

46. Al-Ammar A, Drummond JL, Bedran-Russo AK. The use of collagen cross-linking agents to enhance dentin bond strength. J Biomed Mater Res B Appl Biomater 2009; 91: 419-24.

47. Pioch T, Staehle HJ, Duschner H, García-Godoy F. Nanoleakage at the composite dentin interface: a review. Am J dent 2001; 14: 252-258.

48. Sano H. Microtensile testing, nanoleakage, and biodegradation of resin-dentin bonds. J Dent Res 2006; 85: 11-14.
49. Silva ALF, Araújoa JE, Rochaa GP, Oliveirab AS, Moraesb RB. Solvent content and dentin bond strengths using water-wet, ethanol-wet and deproteinization bonding techniques. Acta Odontologica Scandinavica 2013; 71: 710-15.

50. Montagner AF, Skupien JA, Borges MF, Krejci I, Bortolotto T, Susin AH. Effect of sodium hypochlorite as dentinal pretreatment on bonding strength of adhesive systems. Ind J Dent Res 2015; 26:416-20.

51. Esteves SR, Huhtala MF, Gomes AP, Ye Q, Spencer $P$, De Paiva Gonçalves SE. Longitudinal Effect of Surface Treatments Modified by $\mathrm{NaOCl}-$ Induced Deproteinization and Nd:YAG Laser onDentin Permeability. Photomed Laser Surgery 2016; 34: 68-75.

52. Ferreira MB, Carlini Júnior B, Galafassi D, Gobbi DL. Calcium hypochlorite as a dentin deproteinization agent: Microleakage, scanning electron microscopy and elemental analysis. Microscopy Research and Technique 2015; 78: 676-81.

53. Aguilera FS, Osorio R, Osorio E, Moura P, Toledano M, Bonding efficacy of an acetone/based etch-and-rinse adhesive after dentin deproteinization. Med Oral Patol Oral Cir Bucal 2012; 1: 14-17.

54. Silva GO, Barcellos DC, Pucci $C R$, Borges $A B$, Torres $C R$. Longitudinal bond strength evaluation using the deproteinized dentin technique. Gen Dent 2009; 57:328-333.

55. Torres RGC, Barcellos DC, Batista GR, Pucci CR, Antunes MJ, de La Cruz DB, Borges AB. Five-year clinical performance of the dentine deproteinization technique in non-carious cervical lesions. J Dent 2014; 42: 816-23.

56. Erhardt MC, Osorio R, Viseras C, Toledano M. Adjunctive use of an anti-oxidant agent to improve resistance of hybrid layers to degradation. J Dent 2011; 39: 80-87.

57. Pavan R, Jain S, Shraddha Kumar A. Properties and therapeutic application of bromelain: A review. Biotechnol Res Int 2012; 97-103.

58. Dayem RN, Tameesh MA, A new concept in hybridization: Bromelain enzyme for deproteinizing dentin before application of adhesive system. Contemp Clin Dent 2013; 4: 421-26.

59. Chauhan K, Siddaveerappa R, Basavanna Shivanna V. Effect of bromelain enzyme for dentin deproteinization on bond strength of adhesive system, J Conserv Dent 2015; 18: 360-63. 